Pamiętnik Literacki 2014, 3, s. 79-91
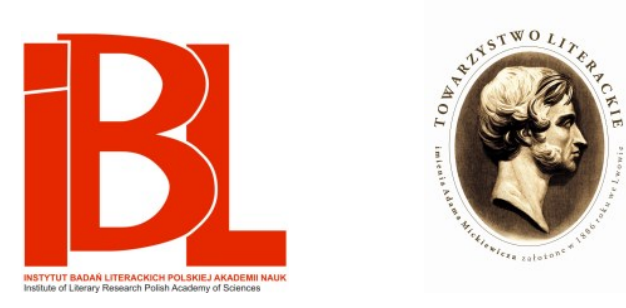

\title{
Gombrowicz i Szekspir
}

\author{
Jerzy Jarzębski
}




\section{GOMBROWICZ I SZEKSPIR}

Jako twórca nowatorskich dramatów Witold Gombrowicz miał jedną cechę, która odróżniała go zdecydowanie od innych przedstawicieli literackiej awangardy: w ogóle się awangardowym teatrem nie zajmował i trudno byłoby znaleźć nazwisko współczesnego mu dramatopisarza, które by aprobatywnie cytował. Witkacy, tak, ale raz - że Gombrowicz interesował się nim głównie jako osobowością, a nie jako autorem sztuk teatralnych (pewnie ich w ogóle nie znał), a dwa - że również jako człowieka-twórce pisarz niezbyt go poważał, już raczej jako jednostkę obdarzoną ponadprzeciętną intuicją, pozwalająca przeczuwać historyczne kataklizmy ${ }^{1}$. Na sugerowane mu pokrewieństwo z Pirandellem bodaj że się zgadzał, ale bez entuzjazmu. Jeszcze bardziej zaskakujący jest stosunek Gombrowicza do reform w dziedzinie teatru: i w tej materii cechowało go raczej wyniosłe désintéressement niż jakakolwiek forma poparcia dla nowatorskich rozwiązań. Argentyńskim teatrem, jak się zdaje, nie interesował się wcale, choć odwiedzał operę, która w Buenos Aires była tradycyjna, bardzo renomowana i położona blisko tras jego codziennych spacerów. Prawdziwa przygoda sztuk Gombrowicza $z$ teatrem zaczęła się dopiero pod koniec jego życia, ale przedstawień polskich widzieć on nie mógł, z kolei zaś słysząc od Diega Massona o eksperymentach Jorge Lavellego w inscenizacji paryskiej Ślubu, jęczał głucho, że wolałby tradycyjny teatr, a zamiast kakofonicznego zbioru dźwięków towarzyszącego przedstawieniu - klasyczną muzykę, „Beethovena albo Chopina"2. Jest to o tyle dziwaczne, że dramat nowatorski szedł wtedy ręka w rękę $z$ reforma teatru: to ona bodaj stanowiła inspirację dla dramatopisarzy, zmieniała bowiem całkowicie sceniczną przestrzeń, status aktora czy też pozycję reżysera. Tymczasem o reformie teatru - i o teatrze w ogóle - Gombrowicz nie miał raczej pojęcia, choć z pewnością odznaczał się niezwykłą intuicją teatralną i wyczuciem konwencji.

W pierwszym swoim dramacie, Iwonie, księżniczce Burgunda, wykorzystał Gombrowicz formułę sceniczną farsy, ale $z$ domieszką Hamleta, co trafnie dostrzegł Krystian Lupa w młodzieńczej inscenizacji tego utworu w krakowskim Starym Teatrze. W Ślubie autor siegnął do Szekspira i Calderona oraz do polskich drama-

1 W. Go mbrowicz, Dziennik 1953-1956. Posł. W. Karpiń s ki. [Oprac. Z. Gór zy na]. Kraków 1997, s. 255-256.

2 R. Gombrowicz, Gombrowicz en Europe: Témoignages et documents 1963-1969. Paris 1988, s. 138. 
tów romantycznych: Balladyny Juliusza Słowackiego ${ }^{3}$ czy Nie-Boskiej komedii Zygmunta Krasińskiego, nie mówiąc już o neoromantycznym Weselu Stanisława Wyspiańskiego, w Operetce - jak sama nazwa wskazuje - do operetki. Wykorzystał je - oczywiście - modyfikując, parodiując, nadpisując tekst własny na kanwie tradycyjnych schematów.

Ale jeśli szukamy śladów Szekspira w pisarstwie Gombrowicza, nie można poprzestać na dramatach. Wielki Anglik obecny był wciąż u autora Ślubu jako swoisty „wzorzec genialności” - bo Gombrowicz chciał właśnie genialnym pisarzem zostać, żadne inne, skromniejsze tożsamości go nie interesowały. W Dzienniku napisał:

Zacząłem szkicować dramat Ślub, już wyraźnie i, powiedziałbym, bezwstydnie nastawiając siebie na genialność, celując w coś na miarę szczytów, na miarę Hamleta lub Fausta, w czym wypowiedziałyby się nie tylko bóle epoki, ale i rodzące się nowe odczuwanie ludzkości... ${ }^{4}$

Łatwo sobie wyobrazić realizację takiego programu zakończoną spektakularną klęską. Bo i cóż łatwiejszego niż - mierzyć w genialność i osuwać się w banał lub grandilokwencję. Tymczasem Gombrowiczowi ta wyprawa w krainę geniuszu udała się lepiej niż wielu innym naśladowcom Szekspira, których w Polsce począwszy od XIX wieku nie brakowało ${ }^{5}$, nawet jeśli geniusz u niego nie był jakością zaistniałą spontanicznie, ale czymś wytworzonym - świadomie, może wręcz z mozołem i nie bez zmysłu parodii ${ }^{6}$. Udała się zapewne dlatego, że polskiego pisarza fascynowały osobowości w Szekspirowskim stylu (niewykluczone zresztą, iż miał w sobie coś z Szekspira w wymiarze psychologicznym), co spowodowało, że nie tylko kreślił swe stylizacje pewną ręką, ale też - że bez wahania modyfikował oryginały, nie bał się sytuacji czy języka osuwających się w groteskę, drastycznych, wykraczających poza to, co w teatrze tradycyjnym przyjęte i dozwolone. Bo „geniusz” to nie tylko wielka tematyka, lecz także śmiałe przełamanie estetycznych przyzwyczajeń, a Szekspira naśladować można $z$ powodzeniem jedynie wtedy, gdy się go przezwycięży, przekroczy w jego artystycznym (językowym czy ideowym) radykalizmie.

W pierwszym, przedwojennym wydaniu Ferdydurke, w Przedmowie do „Filidora dzieckiem podszytego", będącej wykładem literackiego programu autora powieści, Gombrowicz przemawia do swoich kolegów-pisarzy, aby im uzmysłowić, co różni ich od „geniuszy pierwszej klasy”7. Owa drugorzędność, niedostateczność, fascynu-

3 Jak wiele miał wspólnego Ślub z dramatem Słowackiego, udowodnił niedawno W. B ol e c ki (Stowacki Gombrowicza. „Teksty Drugie” 2010, nr 1/2).

4 W. Gombrowicz, op. cit., s. 222.

5 Zob. S. Helsztyński, Szekspir w Polsce. W: W. Szekspir, Dzieła dramatyczne. Oprac. S. Helsztyński, R. Jabłkowska, A. Staniewska. Wyd. 2. T. 6. Warszawa 1964.

6 Zob. M. Głow ińs ki, Parodia konstruktywna. (O „Pornografii” Gombrowicza). W: Gry powieściowe. Szkice z teorii $i$ historii form narracyjnych. Warszawa 1973.

7 Zob. fragment z Przedmowy do „Filidora dzieckiem podszytego” (cyt. z: Nota wydawcy. W: W. G o m b r ow i c z, Ferdydurke. Red. nauk. J. Błoński. Kraków 1986, s. 263): „Sztuka nie egzystuje dla was sama przez się, lecz tylko jako pomost do człowieka. Zbyt skłonni jesteśmy zapominać o naszym zmysłowym uwikłaniu się na amen w częściach ludzkich, o pośredniości, drugorzędności wrodzonej, a przecież to myśl, bez której nie wolno zrobić ani kroku. Każdy, kto piórem wodzi po papierze, mieni się artystą i $z$ tej racji czuje się pokrewny duchom wyjątkowym, jak Szekspir i Goethe - powtarza za nimi, nie bacząc, że słowa ich są w jego ustach jak śpiew słowiczy w dziobie wróbla. Nie przeczę, Dante, Szekspir, Goethe są u siebie w sztuce i wierzę, że gdy piszą 
jąca poniekąd, bo demaskująca człowieka w pisarzu, nie ma rzekomo dotyczyć figur geniuszów literackich, którzy mogą w tej sytuacji zajmować się ze spokojem cyzelowaniem formy swych dzieł. Gombrowicz sądził tak w latach trzydziestych XX wieku, potem jednak zmienił pogląd i już w drugim wydaniu powieści fragment ten usunął. Poddał zatem także geniuszów literatury przygodzie $z$ drugorzędnościa, co nie znaczy, że zrezygnował z zawsze w nim istniejącego i silnie zakorzenionego poczucia hierarchii. Szekspir egzystuje więc nadal w pismach i zachowaniach Gombrowicza jako wzorzec literackiej wielkości, i to na kilku różnych poziomach, a intertekstualna gra, która polski pisarz z nim prowadzi, ma wiele wymiarów.

Ten pierwszy, najbardziej elementarny poziom, na jakim obecny jest Szekspir u Gombrowicza, to poziom cytatów. I tu od razu niespodzianka: cytaty te jakże często są sfałszowane lub przekręcone. Ileż czasu spędziłem wertując wszystkie dramaty Szekspira, w których występuje Percy Hotspur, aby się w końcu przekonać, że ani „cytatu” o brzmieniu: „Percy wziął polot za chyży, albo my, albo on musi spaść niżej”8, ani niczego choćby zbliżonego w żadnym z nich nie ma. Gombrowicz potrafił po prostu „mówić Szekspirem” w tym sensie, że całkiem udatnie imitował rytm i obrazowość jego mowy, ale gdzieżby tam czas tracił na przepisywanie fragmentów $z$ oryginału lub tym bardziej - sprawdzanie poprawności cytatów! Niekiedy więc wydaje się, że zna Szekspira na pamięć, innym razem udowadnia jedynie, że wiersz szekspirowski wszedł mu w krew, ale dokładną znajomością tekstów nie potrafi się wylegitymować. Byłoby to zresztą nierealne tym bardziej, że przynajmniej w Argentynie dostęp do polskich tłumaczeń Szekspira musiał być utrudniony. W takim więc sensie Szekspir był i nie był jednocześnie dla Gombrowicza skarbnicą gnomicznych formuł służacych do opisania świata lub obsługujacych typowe sytuacje międzyludzkie. Gombrowicz zapewne po prostu uważał za rzecz „w dobrym tonie” odwoływać się czasami do Szekspira ${ }^{9}$, tyle że niektóre $z$ tych odwołań były

dramat, lub poemat, wystarcza im sztuka, doczesność przemienia się w wieczność, cząstka w całość. I w twórczości swojej realni sa podwójnie - gdyż mogą wyżywać się w czystej sztuce i dzieła ich mają jednak walor obiektywny, pozostają. Tak tedy, choć niejednokrotnie musi im dolegać zwykła cząsteczkowość, dosyć są potężni, aby się urzeczywistnić w najlepszej swojej cząstce. I mogą kochać sztukę, ponieważ sztuka ich kocha; mogą lubować się wyrazem, ponieważ wyraz im służy - boska rozkoszy potentatów! Ale wy panowie? Wy z waszymi częściami ciała?”

8 W. G o m b r o w i c z, Z diariusza prywatnego Hieronima Poniżalskiego. W: Proza (fragmenty), reportaże, krytyka literacka 1933-1939. Red. nauk. J. Błoński, J. Jarzębski. Wybór i układ J. J arzę bs ki. Kraków 1995, s. 22.

9 Oto przegląd cytatów i kryptocytatów z Szekspira, które pojawiają się w Dzienniku W. G o m b r ow i c z a: „Ale jest we mnie coś niebezpiecznego, / Czego, ci radzę, strzeż się...” (Dziennik 1953-1956, s. 48) - por.: „Ale mam w sobie coś niebezpiecznego, / Czego ci radzę strzec się” (W. Sz e k s pir, Hamlet. W: Dzieła dramatyczne, t. 6, akt V, sc. 1, s. 155 (przeł. J. P a s z k ow s ki〉); „Klęknij, Ryszardzie, by czymś wyższym zostać / Wstań, sir Ryszardzie i Plantagenecie...” (Dziennik 19531956, s. 83) - jest to skondensowany mocno, ale zarazem zgrabnie, skrót wypowiedzi angielskiego króla z tragedii Król Henryk VI: „Schyl się więc, ugnij przede mną kolano: / Za ten znak hołdu królowi złożony / Miecz ci Yorków groźny przypasuję, / Wstań jak prawdziwy teraz Plantagenet, / Wstań teraz, książę Yorku, Ryszardzie” (W. Sze k s pi r, Król Henryk VI. W: Dzieła dramatyczne, t. $4\langle 1963\rangle$, cz. 1, akt III, sc. 1, s. 59 〈przeł. L. Ulri c h〉); „Biada podrzędnym istotom, gdy wchodzą / Pomiędzy ostrza potężnych szermierzy!" (Dziennik 1953-1956, s. 96) - dokładny cytat z Hamleta Szekspira (akt V, sc. 2, s. 160); „Idzie na ciebie, Makbecie, zielony, szumiący las!...” (Dziennik 1961-1969. Posł. W. Karpińs ki. [Oprac. Z. Górzyna]. Kraków 1997, s. 29) - kryptocytat. 
„puste”. Zamieszczone tu w przypisie odesłania do tekstów Szekspira, które pojawiły się w Dzienniku, dają do myślenia, pokazują bowiem nie tylko, jak silna była obecność autora Hamleta w świadomości Gombrowicza, ale także - iż tę obecność czasami wspierała dokładna pamięć, pozwalajacca bezbłędnie reprodukować oryginał, niekiedy pamięć mniej lub bardziej zdefektowana, wreszcie ogólnikowa „pamięć stylu” lub pamięć ogarniająca występujący u Szekspira konflikt dramatyczny i jego bohaterów, lecz już nie konkretne cytaty. Tak czy inaczej, Gombrowicz odznaczał się pierwszorzędną znajomością Szekspirowskiej dramaturgii: odwoływał się przecież nie tylko do dramatów powszechnie znanych: Hamleta i Makbeta, ale też do stosunkowo mniej popularnych - Henryka V czy Henryka VI.

Dużo ciekawsza jest obecność Szekspira w planie konstrukcyjnym sztuk Gombrowicza. Tu podobieństwa są zarówno znacznie bardziej istotne, jak i - mocniej usadowione w samej formie utworu. Gombrowicz jako dramaturg zdaje się bowiem „myśleć Szekspirem” i wręcz odruchowo stosować szekspirowskie z ducha rozwiązania poszczególnych wątków. Zacznijmy od tego, co najważniejsze, czyli od zasady konstrukcyjnej dramatów. Są one jednocześnie dramatami władzy i dramatami rodzinnymi, tak samo jak najsłynniejsze sztuki Szekspira - Hamlet, Makbet, Król Lir. Gombrowicz, podobnie jak Szekspir, dostrzega, że to mechanizm uzależnień w rodzinie jest wzorcem dla konfliktów powstających w świecie władzy. Nic dziwnego zresztą: dawne systemy dynastyczne były przecież przeniesieniem w sferę polityki zasad rządzących dziedziczeniem w ówczesnych rodzinach.

Dlatego jeden z najważniejszych konfliktów u Gombrowicza to konflikt między starym a młodym pokoleniem. Filip z Iwony, księżniczki Burgunda chce udowodnić rodzicom i dworowi, że jest prawdziwym, tzn. suwerennym w swoich decyzjach władca - i dlatego postanawia ożenić się z niepociagającą Iwoną, czyli sprzeniewierzyć się dworskim nakazom, wedle których powinien poślubić najładniejszą pannę. Dodajmy, że Filip jest księciem po trosze operetkowym (operetka przedstawiała dwór na miarę mieszczańskiego widza, dla którego była przeznaczona), dlatego właściwością jego wybranki musi być uroda i uznana powszechnie atrakcyjność - walory łatwe do potwierdzenia przez widownię uwielbiającą brylujące na scenie gwiazdy a nie np. przynależność do wielkiego rodu, istotna $z$ uwagi na jakieś układy dynastyczne. Henryk ze Ślubu najpierw wynosi swego ojca, karczmarza, do królewskich godności, a potem ulega podszeptom Pijaka i obala go, poddając następnie oboje rodziców rozmaitym upokorzeniom. $Z$ kolei jego celem najważniejszym jest poślubienie Mańki, służącej w karczmie rodziców, dawnej swej narzeczonej, i podniesienie jej tym samym do najwyższych godności. Ten tytułowy ślub dopiero pozwoliłby mu założyć rodzinę, czyli spełnić warunki, które polityka stawia władcy - zobowiązanemu do przedłużania swego rodu i prowadzenia jakiejś polityki dynastycznej.

W Operetce natomiast księstwo Himalaj rządzą operetkowym niby to państew-

Najbliższa mu jest chyba wypowiedź Żołnierza: „Kiedy odbywałem wartę / Owdzie na wzgórzu, spojrzałem ku Birnam: / Wtem las, zdawało mi się najwyraźniej, / Zaczął się ruszać z miejsca” (W. Szeks pir, Makbet. W: Dzieła dramatyczne, t. 5〈1963〉, akt V, sc. 5, s. 915〈przeł. J. Pa szkow s ki )); „Nie urodzone jeszcze pokolenia / Przeklinać będą ten żarcik Delfina!” (Dziennik 1961-1969, s. 40) - niemal dokładny cytat z Życia Henryka V W. Sze k s pir a (w: Dzieła dramatyczne, t. $3\langle 1963\rangle$, akt I, sc. 2, s. 498 〈przeł. L. Ulri ch〉). 
kiem nie tyle jako bytem politycznym, ile jako obszarem, w którym narzucają wszystkim zasady smaku i mody. Tam wprawdzie kwestia dziedziczenia władzy nie odgrywa większej roli, ale znów kandydatka na kochankę syna Himalajów, Szarma, która nie chce podporządkować się regułom dyktowanym przez dwór, sprawia rodzicom poważne kłopoty. Niedokończona Historia zaczyna się wprawdzie w mieszczańskim domu, w którym syn - a jakże! - buntuje się przeciw rodzicom, ale wkrótce ten sam schemat buntu zostanie przeniesiony na rosyjski, potem na niemiecki dwór cesarski.

Zauważmy, iż we wszystkich utworach akcja rozgrywająca się zrazu w mieszczańskim domu przenosi się na dwór królewski - albo odwrotnie: dwór, na którym toczą się wypadki, coraz dobitniej i wyraźniej okazuje się mieszczańskim salonikiem. To pomieszanie stylów, zestawienie dostojeństwa panujących bądź z prymitywnym, chłopskim językiem (Ślub), bądź ze stylem farsowym lub operetkowym, wykluczającym powagę tragedii (Iwona, Operetka), staje się specjalnością Gombrowicza. Podobieństwo do Szekspirowskich dramatów okazuje się czymś względnym, bo tam swiaty bohaterów wysokich i niskich współistniały wprawdzie, ale pozostawały wyraźnie rozdzielone, Gombrowicz natomiast je łączy w tych samych osobach. Autor Ślubu zdaje się czerpać $z$ dwóch naraz szekspirowskich źródeł: $\mathrm{z}$ jednej strony rozwija w swoich dramatach wątek rodzinnych konfliktów nałożonych na konflikty polityczne i walkę o władzę, $z$ drugiej - łączy poetykę wysoką i niską, jak to się często przydarzało w Szekspirowskich tragediach. Ale u niego tożsamość społeczna scenicznych postaci jest zachwiana (dlatego mogą być na zmianę feudalnymi władcami - i chłopami czy mieszczańskimi arywistami), stała się bowiem już nie istotą osobowości, lecz odgrywaną okazjonalnie rolą, zresztą najczęściej narzucaną z zewnątrz przez otoczenie albo przez sytuację.

Najważniejszym szekspirowskim motywem u Gombrowicza wydaje się sukcesja pokoleń związana $\mathrm{z}$ walką o władzę. Bohaterowie sztuk tego autora zwykle są młodymi dziedzicami rodzicielskich tytułów monarszych (Iwona, Ślub), rodzicielskiego autorytetu i arystokratycznej schedy (Operetka, Historia). Zresztą ich role przenikają się i zmieniaja. Wszystko to przypomina nieco konstrukcję kronik historycznych Szekspira. Ale młodzi adepci mają kłopoty ze sobą i chcieliby zaistnieć na innych zasadach niż ich rodzice. Filip z Iwony jest księciem - sukcesorem tronu, lecz chciałby, jak zaznaczyłem wcześniej, decydować o sobie i uwolnić się od kurateli dworu, który narzuca mu wzorce postępowania. Wspominałem już, że w jednej z pierwszych swoich inscenizacji wystawiajacy Iwonę w krakowskim Starym Teatrze reżyser Krystian Lupa ucharakteryzował Filipa na Hamleta: ubrał go na czarno i jego atrybutem uczynił trzymaną w ręku książkę. Na pozór sytuacja księcia u Gombrowicza niezbyt przypomina sytuację w Hamlecie: król nie uzyskał tronu wskutek dokonanej zbrodni, królowa nie poślubiła zabójcy męża, Iwona niewiele ma wspólnego z Ofelią, itd. Wszelako liczą się inne czynniki: król wraz z szambelanem przyznają się do uwiedzenia w młodości prostej dziewczyny z ludu, która potem zabiła się, królowa pisze grafomańskie wiersze, które ukrywa przed najbliższymi z wyjątkiem dwórki-powiernicy, a zatem świetność dworu podszyta jest grzechem - i to, co gorsza, grzechem popełnianym przez „Najwyższych” w porozumieniu $z$ poddanymi, więc tym bardziej degradującym. Inni dworacy także mają na sumieniu różne grzeszki, zatem w końcu sprzysięgają się przeciw Iwonie, chcąc ją 
usunąć. I kiedy motyw zabójstwa staje się na dobre farsowy, wkracza znów Szekspir: królowa, by móc zabić Iwonę, stylizuje się na lady Makbet, zresztą w równie farsowy co uprzednio sposób.

Książę Filip wraca na koniec w objęcia dworskich rytuałów - ginie tylko nisko urodzona Iwona, zabita przez dwór „z wysoka”, ale zadana jej śmierć jest śmiercią, odpowiednio do charakteru postaci, „niską”: sterroryzowana przez dwór Iwona ze strachu dławi się ością ryby. Nie ma więc u Gombrowicza mowy o zachowaniu reguł klasycznej tragedii, nawet w jej niezbyt ortodoksyjnej, szekspirowskiej wersji. Ale przecież bunt Filipa przeciw dworowi i królewskim obyczajom mieści się dobrze w konwencjach klasycznego teatru uwieczniającego dramaty władzy i pokoleniowe konflikty. Tyle że antyczne bądź szekspirowskie wzorce Gombrowicz odczytuje za pośrednictwem albo XIX-wiecznego polskiego dramatu romantycznego, albo mieszczańskiego teatru końca XIX stulecia: operetki, farsy. W ten sposób wątki Szekspirowskie zanurzone zostają w innej stylistyce, odbierającej im powage i pierwotnie istniejacy w nich monumentalizm. Osobny, bardzo ważny problem, który u Gombrowicza zyskuje nowa, odmienną od Szekspirowskiej wykładnię, to problem Boga i jego ingerencji w dramatyczne zdarzenia. Hamlet $z$ początku nie ma stuprocentowej pewności, czy przemawiający do niego duch Ojca jest rzeczywiście postacią zmarłego króla, czy też podszywającego się pod niego diabła. Dlatego musi sprawdzić zasadność oskarżenia, inscenizując odpowiednio występ aktorów. W każdym razie pytanie o naturę inspiracji płynącej z zaświatów stanowi bardzo ważną w dramacie Szekspirowskim kwestię.

W Ślubie wygląda to inaczej, bo punktem wyjścia jest tam świat, w którym kościół - już na samym wstępie dramatu - został zrujnowany, a wraz z nim autorytet (ojcowski, królewski) pochodzacy „z Bożego nadania”. Cała akcja utworu obraca się wokół problemu, skąd w świecie bez Boga bierze się hierarchia osób i w ogóle jakakolwiek władza. I ten problem ma charakter stricte historyczny. Nie można więc chyba przyznać racji Michałowi Głowińskiemu, który twierdzi, że akcja Ślubu rozgrywa się w świecie ahistorycznym ${ }^{10}$. Nie darmo w zapiskach autora na marginesach ocalonego egzemplarza argentyńskiego wydania dramatu Pijak nazwany zostaje „ambasadorem Hitlera”. Kilka lat temu Stefan Chwin, na jubileuszowej sesji gombrowiczowskiej w Krakowie, poświęcił bardzo ciekawy referat problemowi Hitlera i „niewinności” inspirowanych przezeń do zbrodni tłumów jako jednej z najważniejszych kwestii pojawiających się u Gombrowicza ${ }^{11}$. Ta zdecydowanie XX-wieczna problematyka wykracza wyraźnie poza zespół szekspirowskich motywów w dramacie. Natomiast Głowiński ma niewątpliwą rację, gdy pisze o szekspirowskiej naturze protagonisty Ślubu:

Główny bohater jest także bohaterem szekspirowskim, jest Hamletem, rzuconym w świat nieszekspirowski, ale przecież jakoś do szekspirowskiego podobny. Henryk nie tylko uczestniczy w pewnej serii wydarzeń, nie tylko jest ich - w takiej czy w innej formie - sprawca, przede wszystkim problematyzuje

10 M. Głowińs ki, Komentarze do „Ślubu”. W zb.: Gombrowicz i krytycy. Wybór, oprac. Z. Ła p iński. Kraków-Wrocław 1984, s. 641.

11 S. Ch w in, Gombrowicz i Niemcy. W zb.: Witold Gombrowicz nasz wspótczesny. Materiały międzynarodowej konferencji naukowej $w$ stulecie urodzin pisarza. Uniwersytet Jagielloński - Kraków, 22-27 marca 2004. Red. J. Jarzębski. Kraków 2010. 
swoją sytuację, jest ona przedmiotem nieustannych jego pytań (bardzo zasadniczych). I czyni to niezależnie, na jakim etapie swej metamorfozy się znajduje; zarówno jako żołnierz we Francji, jak i następca tronu, aż wreszcie - jako tyrański król. Mamy tu do czynienia ze swoistym rozdwojeniem osobowości: problematyzacja swej sytuacji i działanie na scenie wypadków przestało być u Gombrowicza jednością (u Szekspira była to jedność niewątpliwa), refleksyjny komentarz może nie przylegać do czynu. Pod grozą pewnej schematyzacji powiedzieć możemy, że owo rozdwojenie ma ścisły odpowiednik formalny: w podziale na monologi i dialogi. Dialogi to sfera czynów, monologi są dziedziną refleksji i pytań, właśnie problematyzujących wyjaśnień. Pierwsze tworzą domenę zewnętrzności, drugie - wewnętrzności. To wszakże jest pewne: problematyzując, monologi Henryka należą do ogólnej dramatycznej gry, choć o czym za chwilę - mogą być interpretowane jako załamanie iluzji scenicznej ${ }^{12}$.

To bardzo celna uwaga: bohaterowie Gombrowicza zastanawiają się wciąż nad sobą, są autorefleksyjni do szpiku kości, bo nie wiedzą dokładnie, kim są ani jaką rolę społeczna mają do odegrania. W ten sposób analizują siebie zarówno Filip z Iwony, jak Henryk ze Ślubu czy nawet Witold-Bosonóg z Historii. Na pozór najmniej dotyczy to bohaterów Operetki - bo oni przyszli do sztuki Gombrowicza z gatunku skrajnie skonwencjonalizowanego. Ale ich właśnie kryzys tożsamości dotyczy w trybie niejako zbiorowym i jest znacznie cięższy: wykorzenieni ze swego świata, który uległ ostatecznej destrukcji, starają się wszyscy ukryć pod absurdalnymi maskami (Książe-lampa, Księżna-stolik, Proboszcz-kobieta); jedynie mistrza Fiora stać na autorefleksję i próbę zrozumienia nowej sytuacji, w jakiej znalazł się świat.

Rzecz jasna, najbardziej szekspirowski $z$ bohaterów Gombrowicza okazuje się Henryk - już począwszy od jego kondycji podstawowej: że jest człowiekiem śniącym, a świat, w którym się znajduje, to świat jego snu. Wiadomo doskonale i z pierwszej ręki, że motyw snu wziął Gombrowicz ze sztuki Calderona de la Barca Życie snem, którą się zachwycał w rozmowach prowadzonych ze swym przyjacielem i zarazem tłumaczem Ślubu na język hiszpański, Alejandrem Rússovichem, w latach czterdziestych XX wieku w Buenos Aires. Ale czy wątków szekspirowskich w tym nie ma? Sen i motywy nadnaturalne, $z$ piekła lub $z$ niebios rodem, odgrywają równie ważną rolę u autora Hamleta: warto przypomnieć Burzę, w której Ariel na polecenie Prospera usypia grupkę rozbitków z okrętu króla Neapolu. Jeszcze ważniejszy jest ten motyw w Śnie nocy letniej. Z kolei bohaterowie Gombrowicza, podobnie jak ich starsi bracia z Szekspira, choć we snach grzęzną, wcale o swym stanie zdają się nie wiedzieć - $z$ wyjątkiem samego Henryka, który grozi im w jednej ze scen, że ich unicestwi, budząc się. Do tego dochodzi u Szekspira dwuznaczna, ale wielce istotna rola zaświatów i magii: wiedźmy z Makbeta, które swymi przepowiedniami rozpalają w tytułowym bohaterze nieokiełznane ambicje i uwalniają ukryte w ludzkiej naturze zło, pojawienie się widm - Banka w Makbecie czy Ojca w Hamlecie - wszystko to sprawia, że świat Szekspirowskich dramatów bliski jest onirycznemu światu sztuki Gombrowicza, że, jak to bywa ze snami, rodzą nieustannie pytania i wątpliwości jako tajemniczy przekaz symboliczny, poddający się wciąż nowym interpretacjom. Harold Bloom pisze:

August Wilhelm von Schlegel zauważył słusznie w r. 1809, że „Hamlet nie znajduje wyraźnej ulgi ani w sobie, ani w czymkolwiek pochodzącym z zewnątrz" - włączając w to, dodałbym, Boga i język. Ma się rozumieć, jest jeszcze Horacjo, którego Hamlet notorycznie przecenia, Horacjo jednak zdaje się 
istnieć tam tylko po to, by uosabiać miłość widowni do Hamleta. Horacjo jest dla nas mostem wiodącym $\mathrm{w}$ to, co na zewnątrz, w tę dziwną, ale wyraźnie negatywną transcendencję, która wieńczy tragedię ${ }^{13}$.

Trudno nie dostrzec w opisanej przez Blooma relacji pomiędzy Hamletem, Horacjem i światem zewnętrznym zapowiedzi podobnej relacji wiążącej Henryka, Władzia i świat spoza snu Henryka w Ślubie.

Ale wątki szekspirowskie w Ślubie - zanim znalazły się u Gombrowicza - przepuszczone zostały przez jeszcze jedno medium: to polski dramat romantyczny. Włodzimierz Bolecki udowodnił, jak uważam, najzupełniej przekonująco, że Ślub jest dramatem wyzyskującym $\mathrm{w}$ dużym stopniu wątki brane $\mathrm{z}$ Balladyny Słowackiego, ta $z$ kolei pisana była pod wyraźnym wpływem Szekspira ${ }^{14}$. Polscy romantycy odkrywają Szekspira i wykorzystują jego inspiracje, a już szczególnie specyficzny status scenicznej rzeczywistości, balansującej między realizmem a fantastyka, motyw teatru w teatrze, przeniknięcie się elementów wysokiej tragedii czy moralitetu $z$ niskimi gatunkami krotochwili lub farsy o proweniencji ludowej. Jeśli $z$ tej strony spojrzymy na dramat Gombrowicza, przestanie dziwić przerzucanie się akcji z wiejskiej karczmy na królewski dwór i przeistoczenia bohaterów - karczmarza i jego rodziny w królewską familię, Pijaka w Ambasadora, etc. Umożliwia to poetyka snu, ale jednocześnie stoi za tym długa tradycja dramatu europejskiego. Teza artykułu Boleckiego jest wszakże odmienna od takiego, dość stereotypowego, odczytania obecności Szekspira w polskim dramacie romantycznym. Wedle owej koncepcji, rozpowszechnionej w literaturoznawstwie, zwłaszcza w jego szkolnej wersji, inspiracją szekspirowską dla Słowackiego piszącego Balladynę był przede wszystkim Sen nocy letniej: z tego dramatu miał wziąć poeta cudowność, ironię i baśniowość, dostrzegano także próbę stworzenia - podług szekspirowskich wzorców - „narodowej alegorii historiozoficznej” ${ }^{15}$. Bolecki podkreśla, że sposób, w jaki Gombrowicz w Ślubie posługuje się inspiracją płynącą z Balladyny, równoznaczny jest z próbą reinterpretacji jej szekspiryzmu - autor Ślubu wykorzystuje głównie to, co dramat Słowackiego wiąże raczej z Makbetem: analizę psychologiczną procesu narastającej bezwzględności i moralnej degradacji człowieka biorącego w swe ręce nieograniczoną władzę.

Porównując Ślub z Balladyną dostrzega Bolecki, że:

W Balladynie mamy dwie transformacje „człowieka w króla” (zgodnie ze starym motywem „z chłopa - król"): najpierw królem zostaje pijak, chłop Grabiec (notabene to jedna z prefiguracji Gombrowiczowskiego Pijaka), a następnie Balladyna (jako żona Kirkora). Podobnie w Ślubie mamy dwie transformacje „człowieka w króla”: najpierw królem zostaje karczmarz (ojciec), potem żołnierz (Henryk).

Kluczowa dla każdego z dramatów jest postać głównego bohatera. Transformacja bohatera we

H. Bl o o m, Shakespeare and the Value of Personality. W zb.: The Tanner Lectures on Human Values. Princeton 1995. Na stronie: www.tannerlectures.utah.edu/lectures/documents/bloom97.pdf Pisze B ole cki (op. cit., s. 181-182): „Nie mam wątpliwości, że szekspiryzm dramatów Gombrowicza (Iwona, księżniczka Burgunda oraz Ślub) miał także niezauważone dotąd ogniwo pośrednie - były nimi dramaty Słowackiego. Jeden dramat Słowackiego musiał mieć dla Gombrowicza wyjątkowe znaczenie. Była nim, moim zdaniem, Balladyna”. I dalej: „Ślub jest świadectwem podjęcia przez Gombrowicza problematyki Balladyny (jako intertekstu łączącego dramat Gombrowicza z utworami Shakespeare'a, zwłaszcza Makbetem) [...]" (ibidem, s. 187). 
władcę (Balladyny i Henryka) w obu dramatach otwiera szczelinę pomiędzy społeczną rolą człowieka (władca/król) a jego powinnościami moralnymi ${ }^{16}$.

Dalej dokonuje Bolecki nader przekonującego zestawienia poszczególnych scen tych dramatów, ukazując w końcu, że seria zbrodni popełnianych przez bohaterów, zwłaszcza analogicznych u obydwojga aktów wyparcia się związków z własnymi rodzicami, prowadzi w finale do wymierzenia sprawiedliwości każdemu $z$ władców, przy czym „Słowacki - zgodnie z romantyczną konwencja - źródło zła moralnego przedstawia jako działanie diabła [...]. Gombrowicz źródłem zła czyni presję międzyludzkich relacji, którym ulega pojedynczy człowiek". W rezultacie Balladyna przyznaje się do winy i ginie od pioruna - Henryk nie czuje ani winy, ani odpowiedzialności, a kara spada nań jako „formalna konsekwencja wcześniejszej decyzji”"17.

Nie lekceważyłbym aż tak jak Bolecki wątków magii czy cudowności u Słowackiego. Ostatecznie u niego, jak i u Szekspira, pełnią one bardzo ważna funkcję: z cudowności - jako swoistej „mgły”, sfery niejasnej co do pochodzenia i nacechowania moralnego, wyłaniają się wobec bohaterów mgliste obietnice i sugestie działania, którym ci się poddają - często $\mathrm{z}$ fatalnym dla siebie skutkiem. Gombrowicz dokonuje tu manewru niejako „socjologizacji” owych obietnic i sugestii: stają się one u niego pokusami tworzonymi przez „kościół międzyludzki”, narzucający bohaterom formę, obdarzający godnością i władzą, nie zapewniający jedynie moralnego sensu egzystencji.

Powróćmy raz jeszcze do artykułu Głowińskiego. Powiada on, że obficie występujące w tekście Ślubu monologi Henryka - jako forma we współczesnym teatrze raczej nie używana - należą do tradycji szekspirowskiej i są przez Gombrowicza traktowane wręcz jako parodia monologów postaci Szekspira ${ }^{18}$. Ale funkcja parodystyczna nie jest tu chyba najważniejsza. Znacznie istotniejsza wydaje się chwilowa deziluzja, o której Głowiński także zresztą wspomina, pisząc o swoiście metatekstowej funkcji wypowiedzi Henryka ${ }^{19}$. Deziluzja stanowi funkcje pewnej nadświadomości głównej postaci dramatu, która nie tylko działa na scenie, ale też prowadzi wątek autotematyczny, dystansując się od swej roli i analizując własne postępki. To, co było wielkim odkryciem Szekspira i decydowało o nowatorstwie jego dramatów, Gombrowicz powtarza, przydając autoanalizie bohaterów nieco innego, współczesnego tła antropologicznego. To Zdzisław Łapiński w jednym z pierwszych opatrzonych aparaturą naukową tekstów poświęconych Gombrowiczowi zauważył, do jakiego stopnia pisarz jest w swych pomysłach zgodny ze współczesną mikrosocjologiąa20.

Na frontonie szekspirowskiego teatru The Globe miał widnieć napis: TMAH, co było skrótem od „Totus mundus agit histrionem”, czyli „Cały świat gra komedię” albo - po

20 Z. Ła piń s ki, „Ślub w kościele ludzkim”. (O kategoriach interakcyjnych u Gombrowicza). „Twórczośč” 1966, nr 9. 
angielsku - „All the world's a stage”, które to sformułowanie jest fragmentem monologu $\mathrm{z}$ Jak się wam podoba:

\section{All the world's a stage,}

And all the men and women merely players.

They have their exits and their entrances ${ }^{21}$.

Bez wątpienia, trudno byłoby znaleźć zdanie lepiej odzwierciedlające poglądy Gombrowicza na ludzką naturę. Już w jednym ze swoich wczesnych opowiadań zauważa on:

A dlaczegoż to, pytam, w ogóle w życiu publicznym wypada się zgoła inaczej niż w życiu prywatnym? Jedna i ta sama osoba zmienia się do niepoznaki w przejściu $z$ sypialnego do salonu, $z$ salonu zaś do gabinetu pracy. Inna jest, gdy drapie się za uchem, inna, kiedy pisze wiersz; inna, gdy wygłasza sąd swój o upadku moralności, inna zaś, gdy je sznycel z buraczkami. Przeklęta zręcznośćt? ${ }^{22}$

„Przeklęta” - wyjaśni zaraz Gombrowicz - bo sprawia, że choć w życiu prywatnym jesteśmy „bogaci i wszechstronni”, w tym, co piszemy i publikujemy, wypadamy nudno i monotonnie. To oczywiście skutek działania unifikujacej formy, pierwszej i zasadniczej zmory ciążącej na życiu ludzkim od jego zarania, formy przybierającej różne postacie: panującego w danym społeczeństwie obyczaju i konwenansu, języka opisującego rzeczywistość i obowiązującego stylu literackiego, powszechnie przyjętych systemów wartości, wreszcie zespołu kategorii, za których pomoca postrzegamy świat i uczymy się go rozumieć. Człowiek zatem, aby zapanować nad pętającymi go formami, musi nieustannie pamiętać, że nie jest po prostu „sobą”, ale że odgrywa wciąż jakieś społeczne role. W Dzienniku znajdziemy na ten temat rozważania całkiem już jednoznaczne:

Przecież mój człowiek jest stwarzany od zewnątrz, czyli z istoty swojej nieautentyczny - będący zawsze nie sobą, gdyż określa go forma, która rodzi się między ludźmi. Jego „ja” jest mu zatem wyznaczone w owej „międzyludzkości”. Wieczysty aktor, ale aktor naturalny, ponieważ sztuczność jest mu wrodzona, ona stanowi cechę jego człowieczeństwa - być człowiekiem to znaczy być aktorem - być człowiekiem to znaczy udawać człowieka - być człowiekiem to „zachowywać się” jak człowiek, nie będąc nim w samej głębi - być człowiekiem to recytować człowieczeństwo ${ }^{23}$.

Sądy te, zdaniem Gombrowicza, powinny wpływać bezpośrednio na krytykę, bo wynika $z$ nich niezbicie, że autor dzieła nie jest jedynie wytwórca obiektywnie istniejących literackich wartości, ale - że najzupełniej osobiście angażuje się w proces interakcji $z$ odbiorcami, a za pomoca dzieła realizuje jakieś swoje sprawy, wplątuje się też w rozgrywki i działa interesownie, co zresztą żadnym grzechem nie jest. Powiada Gombrowicz w liście do członków Klubu Dyskusyjnego w Los Angeles:

Gdy gracie w tennis, nie usiłujecie wmówić w nikogo, że idzie wam o coś innego poza grą - ale gdy przerzucacie się argumentami, nie chcecie przyznać, że prawda, wiara, światopogląd, ideał, ludzkość albo sztuka stały się piłką, i w gruncie rzeczy ważne jest, kto kogo pokona, kto zabłyśnie, kto się wykaże w owym starciu, tak mile zapełniającym południe. 


\section{$[\ldots]$}

[...] I jeśli literatura w ogóle ośmiela się mówić, to wcale nie dlatego, że jest pewna swojej prawdy, a tylko dlatego, że jest pewna swojej rozkoszy. [...] Zapominamy, że człowiek nie jest po to tylko, aby drugiego człowieka przekonać - że jest po to, aby go pozyskać, zjednać, uwieść, oczarować, posiąść. Prawda nie jest sprawą argumentów tylko - jest sprawą atrakcji, czyli przyciagania. Prawda nie urzeczywistnia się w abstrakcyjnym turnieju idej, ale w starciu osób ${ }^{24}$.

Ciekawy to fragment, bo wydaje się połączeniem Szekspirowskiej idei człowieka-gracza $z$ Barthes'owskim podejściem do literatury jako źródła rozkoszy - tyle że sformułowanym, zanim zrobił to Barthes ${ }^{25}$. Idea człowieka-gracza jest jednym $z$ najbardziej podstawowych konceptów antropologicznych Gombrowicza ${ }^{26}$, przy czym ludzkie aktorstwo pisarz rozumie bardzo poważnie, a zatem nie jako beztroską zabawę formami i rolami, ale jako swoisty test: próbę osobowości, którą człowiek podejmuje po to, by - „czytajacc” aktorską formułę własnego wystąienia - dowiedzieć się, kim aktualnie jest, i ewentualnie starać się odrzucić własną rolę i wybrać inną („nie grać”, „być po prostu sobą” u Gombrowicza się nie da).

Tę ostatnią koncepcję - człowieka jako wieczystego gracza - wolno uznać za najważniejszą z szekspirowskich idei, jakie odnaleźć można u Gombrowicza, wpływa ona bowiem decydująco na rysunek jego postaci, zawsze mających kłopot z określeniem własnej tożsamości, zawsze ją wypróbowujących - trochę na podobieństwo Hamleta, który wydaje się najbliższym Gombrowiczowi wzorcem szekspirowskiego bohatera. Co ciekawe, najistotniejsze bodaj konsekwencje koncepcji człowieka-gracza widać u Gombrowicza nawet nie w dramatach, ale w utworach prozą. Bohaterami tej prozy są zwykle albo postacie noszące imię i nazwisko autora, albo znajdujące się w bliskiej mu sytuacji egzystencjalnej lub psychologicznej. Zarazem bohaterowie ci występują w roli narratorów opowiadanych historii. Mamy więc w prozie sytuację, w której bohaterem utworu jest Gombrowicz, narratorem - Gombrowicz, podmiotem czynności twórczych (implied author) - Gombrowicz i w końcu rzeczywistym, bytującym w pozaliterackim świecie autorem - także Gombrowicz. Każda $z$ ról odgrywanych w tej piramidzie jest rolą przyjętą w danym momencie przez autora, ale jednocześnie każda $z$ nich ma pewną autonomię, nieprzejrzystość, zmusza do interpretacji z zewnątrz. I tak zatem narrator tłumaczy w swej opowieści zachowania bohatera, $z$ kolei opowieść ta jest swoiście interpretowana z pozycji konstruktora tekstu literackiego, w końcu ową konstrukcję objaśnia autor książki w ulubionych przez Gombrowicza autointerpretacjach czynionych spoza tekstu: w artykułach lub przedmowach towarzyszacych utworom literackim bądź np. w Dzienniku albo w Testamencie, czyli rozmowach z francuskim krytykiem, Dominikiem de Roux. Tej piramidzie gier i interpretacji poświęciłem przed laty obszerną analizę we wspomnianej tu już książce Gra w Gombrowicza.

W ten sposób każda z Gombrowiczowskich postaci jest niezliczonymi więzami połączona $z$ innymi postaciami, wobec których odgrywa role, każda też ma skłonność do wysnuwania $z$ siebie sobowtórów i tworzenia pomiędzy nimi sieci zależno-

W. G o mbrowicz, Dziennik 1953-1956, s. 115-116.

R. B arthes, Przyjemność tekstu. Przeł. A. Lew ań ska. Warszawa 1997.

Przed przeszło 30 laty poświęciłem tej sprawie obszerną książkę pt. Gra $w$ Gombrowicza (Warszawa 1983). 
ści. Te cechy konstrukcyjne swych bohaterów wedle wszelkiego prawdopodobieństwa Gombrowicz zawdzięcza Szekspirowi. Nie darmo Joel Fineman pisał w studium o motywie sobowtórów u Szekspira:

W przeciagu całej swej pisarskiej kariery Szekspir posługiwał się schematami symetrycznymi, parami sobowtórów, relacjami w ostro zarysowanej, naznaczonej ironią wzajemnej równowadze. Te struktury opozycyjne są często umieszczone w ramach rodziny - na przykład Komedia omyłek, w której Szekspir zaczął eksperymentować $\mathrm{z}$ forma komediowa, jest po prostu farsa o bliźniętach, a przy tym farsą mechaniczną - ale równie często kontekst rodzinny jest zaledwie sugerowany, nie ujęty w słowa, lecz z góry założony ${ }^{27}$.

Relacja pomiędzy sobowtórami jest bez wątpienia jedną z najważniejszych relacji tworzących dramatyzm utworów Gombrowicza, szczególnie w jego prozie, co wielokrotnie interpretatorzy opisywali ${ }^{28}$. Jeśli nawet układy sobowtórowe postaci były u tego autora wyraźnie odmienne niż, powiedzmy, w Komedii omyłek, gdzie po prostu występują dwie pary bliźniaków, $\mathrm{z}$ czego wynikają liczne nieporozumienia, to sam mechanizm podwojenia stanowi wciąż powtarzany przez Gombrowicza chwyt. Tak jest w Ferdydurke z Józiem i Miętusem, tak w Ślubie z Henrykiem i Władziem, w Trans-Atlantyku z Witoldem i Gonzalem, w Pornografii z Witoldem i Fryderykiem czy w Kosmosie z Witoldem i Fuksem. Sandauer uważał, że postacie sobowtórów głównego bohatera (zawsze mniej lub bardziej utożsamianego $\mathrm{z}$ autorem) służyły Gombrowiczowi do maskowania, homoseksualnej najczęściej, perwersji. Bohater jest bowiem „normalny” - odium za perwersję spada na sobowtóra. Takie ujęcie wydaje się grubym uproszczeniem. Układy sobowtórowe są u Gombrowicza za każdym razem inne, a ukrywanie homoseksualnych skłonności głównego bohatera stanowi tylko jedną $\mathrm{z}$ wielu funkcji, jakie pełni sobowtór. Jest on bowiem lustrem, w którym przeglądają się rozmaite cechy Witolda, zyskując wyrazistość i definicję. Poza tym gra prowadzona przez pary bohaterów wiedzie do rozpoznania przez nich nie tylko charakteryzującej obydwu fascynacji, ale też struktury i właściwości świata, który inaczej pozostałby niejasny, pozbawiony określonego sensu. Dopiero dzieląc się swoimi spostrzeżeniami sobowtórowi bohaterowie nadają mu znaczenia i uzgadniaja strategie działania. Najlepiej to widać w Pornografii, gdzie Witold i Fryderyk prowadzą ze sobą dość skomplikowaną grę, wymieniają listy i czynią sobie (pół)zwierzenia.

Wydaje się to nadzwyczaj „szekspirowskie”. Wielcy bohaterowie dramatów Szekspira: Hamlet, Makbet, Otello, cierpią zrazu na pewnego rodzaju nieokreśloność, podobnie nieokreślony, nie do końca zrozumiały i wyrazisty jest dla nich świat, w którym żyją. Aby dojść do autodefinicji i wyostrzonej (nawet jeśli fałszywej) wizji rzeczywistości, muszą siebie samych „zagrać” wobec innych, przeglądając się w nich zarazem. Na tej drodze Hamlet utwierdza się w chęci zemsty na matce i stryju, Makbet - w żądzy nieograniczonej władzy i godności, Otello - w zazdrości guage in Shakespeare's „Hamlet”. „Chrestomathy” t. 2 (2003). Autorka dostrzegła rozpowszechnione u Szekspira zjawisko gier słownych i kalamburów. Korzystał z nich również Gombrowicz. 
o Desdemonę. Cały ten proces kreacji własnego „ja”, określania natury własnego uwikłania w świat i innych ludzi, naczelnej obsesji rządzącej postępowaniem wygląda u Gombrowicza, zwłaszcza w Ślubie, podobnie jak u Szekspira. Także inne charakterystyczne dla Szekspirowskich dramatów motywy, o których pisze Fineman: bratobójstwo i „przyprawianie rogów”, znajdują się w centrum utworów Gombrowicza (szczególnie dobrze widać ich rolę w Ślubie ${ }^{29}$ ), z czego wnioskować wolno, że psychoanaliza obydwu autorów dałaby może zbliżone rezultaty.

Jacek Zembrzuski, reżyser, który wystawiał Ślub w rosyjskim teatrze dramatycznym w Wilnie w roku 1994, powiedział, omawiając koncepcję swego przedstawienia, że Ślub zaczyna się tam, gdzie kończy się polski teatr romantyczny, czego symbolem jest pierwsza scena dramatu $-z$ jej wzniosłym bełkotem i ruinami w tle. Można się z tym zgodzić, zważywszy wspomniane już występowanie w Ślubie nawiązań do Balladyny czy Nie-Boskiej komedii, a zarazem destrukcję romantycznych motywów i języka. Ślub jest więc już wolny od stylistyki Słowackiego i Krasińskiego, co nie znaczy, że ponad ich głowami nie sięga dalej jeszcze w przeszłość. Charaktery osób, relacje między bohaterami, formowanie się tożsamości, refleksja ,ja” nad soba samym - to wszystko u Gombrowicza wydaje się ukształtowane pod wielkim wpływem Szekspira. I jeśli nawet Gombrowicz wymienia znacznie więcej ważnych dla siebie pisarzy (warto tu pamiętać zwłaszcza o Calderonie i o Dostojewskim), to Szekspir jest chyba najważniejszy, jako ten, kto autorowi Ferdydurke „ustawił głos” i od wczesnej młodości nauczył zaglądania w siebie, świadomej autokreacji, zapisanej i poświadczonej przez twórczość. Czy sprawił, że polski pisarz stał się „geniuszem Gombrowiczem”? To rzecz literackiego gustu. Ale przynajmniej zaszczepił mu pewien „zmysł genialności”, poczucie, że literatura - niezależnie, jak bardzo nasycona została grą, humorem, parodią - gdzieś w głębi jest sprawą śmiertelnie poważna, w której najzupełniej serio chodzi o życie i jego sens, o dobro i zło, o porządek świata i zaświatów.

\author{
Abstract \\ JERZY JARZEBBSKI Jagiellonian University of Cracow
}

\title{
GOMBROWICZ AND SHAKESPEARE
}

As an innovative dramatist, Gombrowicz, strangely, expresses little interest in avant-garde theatre and drama of his epoch. More often, though, he refers to traditional form of performance and world classics, especially to Shakespeare's dramas which he exploits to replicate in the theatre Shakespearian gesture and his brilliancy. To achieve that Gombrowicz quotes or cryptoquotes Shakespeare, imitates the form and construction of his works, taking advantage of the overlap of home drama structures and the drama of power, generation gap, the technique of "theatre in theatre," and ultimately the fundamental moral and metaphysical questions. Gombrowicz's concept of man as an eternal player is also adopted from Shakespeare. What mediates between Gombrowicz and Shakespeare's plays is Polish romantic drama, especially Balladyna, seen as Macbeth motifs replica, and $19^{\text {th }} \mathrm{c}$. middle-class drama. In this way Gombrowicz brings Shakespearian issues closer to our times and to modern concept of man in order to once again pose the same great philosophical questions.

Na pozór motywem naczelnym jest w Ślubie ojcobójstwo, ale sprężynę dramatyczną uruchamia w sztuce sprowokowane przez Henryka samobójstwo Władzia, który pełni najwyraźniej funkcję „brata” głównego bohatera. 